\title{
KEBIJAKAN PERWAKAFAN DI INDONESIA (KAJIAN SEJARAH DAN PERUNDANG-UNDANGAN)
}

\author{
Oleh : Mursyid \\ Dosen Univ. Widyagama Mahakan Samarinda dan STAIN Samarinda
}

\begin{abstract}
ABSTAK
Kebijakan perwakafan di Indonesia mengalami fluktuasi dalam pengembangannya.. Bijblad yang pernah dikeluarkan pada masa Hindia Belanda dan Pra Kemerdekaan, kebanyakan hanya untuk keperluan administratif semata.

Sementara pada masa kemerdekaan dan era reformasi, kebijakan perwakafan menunjukkan adanya perubahan yang signifikan. Ini terbukti dengan lahirnya beberapa peraturan pelaksanaan perwakafan, baik yang melekat dengan adat istiadat masyarakat, seperti tanah Perdikan di Jawa Timur, tanah Pareman di Lombok dan Huma Serang di Banten atau dalam bentuk peraturan perundang-undangan, seperti Undang-undang Pokok Agraria, Peraturan Pemerintah No. 28 Tahun 1977, Inpres No. 1 tahun 1991 sampai kepada lahirnya UU No.41 tahun 2004. Hadirnya UU 41 tahun 20014 merupakan buah dari fatwa MUI tentang Wakaf Uang tanggal 28 Syafar 1423 H / 11 Mei 2002 dan merupakan jawaban atas bergulirnya wacana wakaf tunai yang digagas oleh Prof. M. A. Mannan yang menyebutkan bahwa wakaf adalah sebagai Financial Instrument, Social Finance and Voluntary Sector Banking.
\end{abstract}

Kata Kunci : Regulasi, Wakaf, Historis, bijblad

\section{PENDAHULUAN}

Dilihat dari sisi yuridis formal, dengan berlakunya undang-undang 1945 pasal 29 ayat (2) yang menyatakan bahwa negara menjamin kemerdekaan tiap-tiap penduduk untuk memeluk agama masing-masing dan beribadat menurut agama dan kepercayaannya itu, berarti bahwa hukum Islam berlaku bagi penduduk yang memeluk agama Islam. Dari sini sebenarnya terlihat bahwa perkembangan tata hukum yang di alami oleh Bangsa Indonesia dipengaruhi oleh mayoritasnya umat Islam di Indonesia.

Bentuk Yuridisprudensi dan perundang-undangan ini, walaupun dalam penerapannya masih "malu-malu" dengan materi hukum Islam itu sendiri, merupakan cerminan bahwa instrumen Islam sangat diterima oleh penentu kebijakan negara dan bahkan menjadi salah satu perhatian pemerintah dan DPR melalui fungsi legislasinya.

Sejarah juga mencatat bahwa regulasi perwakafan Indonesia mengalami pasang surut dan fluktuasi sesuai dengan kepentingan pembuatnya dan akhirnya potensi wakaf untuk membangun kesejahteraan umat menjadi tidak maksimal adanya. Kita sebut saja hasil investigasi Tim Bimbingan Masyarakat Islam dan Penyelenggaraan Haji tahun 2004 yang mengumpulkan data tentang perkembangan tanah wakaf di Kalimantan dengan peruntukan dan alokasi sebagai berikut: langgar terdapat pada 4.867 lokasi, masjid terdapat pada 4.069 lokasi, kuburan / makam terdapat pada 2.002 lokasi, Madrasah / Sekolah terdapat pada 1.332 lokasi, sosial dan lain-lain terdapat pada 1.295 lokasi $^{1}$

\footnotetext{
${ }^{1}$ Lihat Tim Ditjen Bimas Islam dan Penyelenggara Haji Depag RI, Klasifikasi Pemanfaatan Tanah Wakaf se Sumatera dan Kalimantan, Direktorat Pengembangan Zakat dan Wakaf Jakarta; Ditjen Bimas Islam dan Penyelenggara Haji, 2005, hal. 156
} 
Dari data diatas, terlihat jelas bahwa pemanfaatan tanah wakaf lebih kepada memperlancar pelaksanaan ibadah mahdhah semata, tanpa ada upaya untuk pemanfaatan tanah wakaf tersebut bagi kesejahteraan umat. Fenomena ini terjadi disebabkan: Pertama, minimnya pengetahuan dan atau fanatisme mazhab tertentu sehingga mengakibatkan para nazir berfaham bahwa harta wakaf bersifat statis dan konsumtif, kedua, belum memadainya regulasi wakaf yang berakibat kepada sering terjadinya tumpang tindih atau bahkan harta wakaf menjadi hilang akibat orang-orang yang tidak bertanggung jawab.

Hadirnya makalah singkat ini akan mencoba mengekplorasi peraturan perwakafan yang sudah ada dan telah berjalan selama ini di Indonesia mulai Hindia Belanda, pra kemerdekaan, masa kemerdekaan dan era reformasi sembari berharap agar dari hari kehari regulasi perwakafan ini dapat menjadi telaahan bersama untuk kemudian menjadikannya sebagai pedoman bagi pengelolaan wakaf di Indonesia menuju kesejahteraan ummat.

\section{TINJAUAN PUSTAKA}

\section{A. Pengertian Wakaf}

Menurut arti kata, Wakaf berasal dari kata bahasa arab Waqafa yang artinya menahan atau berhenti ditempat. Perkataan wakaf juga dikenal dalam istilah ilmu tajwid yang bermakna menghentikan bacaan, baik seterusnya maupun untuk mengambil nafas sementara. Bahkan wakaf dengan makna berdiam ditempat juga dikaitkan dengan Wukuf yakni berdiam di Arafah pada tanggal 9 Zulhijjah ketika menunaikan Ibadah Haji. ${ }^{2}$ Menurut istilah, wakaf adalah penahanan harta yang dapat diambil manfaatnya tanpa musnah seketika dan untuk penggunaan yang mubah serta dimaksudkan untuk mendapatkan keridhaan Allah. ${ }^{3}$

Secara harfiah wakaf bermakna "Pembatasan" atau "Larangan". Sehingga kata Waqf (Jama': Auqaf) digunakan dalam Islam untuk maksud "pemilikan dan pemeliharaan" harta benda tertentu untuk kemanfaatan sosial tertentu yang ditetapkan dengan maksud mencegah penggunaan harta wakaf tersebut diluar tujuan khusus yang telah ditetapkan tersebut. ${ }^{4}$

Abu Bakar Jabir Al-jazairi mengartikan wakaf sebagai penahanan harta sehingga harta tersebut tidak bisa diwarisi, atau di jual, atau dihibahkan, dan mendermakan hasilnya kepada penerima wakaf. ${ }^{5}$

Sementara dalam UU RI No. 41 Tahun 2004 tentang wakaf, di sebutkan bahwa wakaf adalah perbuatan hukum wakif untuk memisahkan dan/atau menyerahkan sebagian harta benda miliknya untuk dimanfaatkan selamanya atau untuk jangka waktu tertentu sesuai dengan kepentingannya guna keperluan ibadah dan/atau kesejahteraan umum menurut syariah. ${ }^{6}$

Dalam perspektif ekonomi, wakaf dapat di definisikan sebagai pengalihan dana (atau aset lainnya) dari keperluan konsumsi dan menginvestasikannya ke dalam aset produktif yang menghasikan pendapatan untuk konsumsi di masa yang akan datang baik oleh individual ataupun kelompok.

Dari beberapa definisi diatas, mengindikasikan sifat abadi wakaf atau dengan ungkapan lain, istilah wakaf diterapkan untuk harta benda yang tidak musnah dan manfaatnya dapat

\footnotetext{
${ }^{2}$ Mohammad Daud Ali, Sistem Ekonomi Islam; Zakat dan wakaf, Cet. I, Jakarta; UI Press, 1988, hal. 180

${ }^{3}$ Achmad Azhar Basyir dalam Imam Suhadi, Wakaf Untuk Kesejahteraan Umat, Yogyakarta; PT. Dama Bhakti Prima Yasa, 2002, hal. 18

${ }^{4}$ John L. Esposito, Ensklopedi Oxford Dunia Islam Modern, Jilid 6, Alih Bahasa Eva Y.N dkk, Cet. I, Bandung; Mizan, 2001, hal.145

${ }^{5}$ Abu Bakr Jabir Al-Jazairi, Ensklopedi Muslim (Minhajul Muslim), Alih Bahasa Fadli Bahri, Cet.VII, Jakarta; PT. Darul Falah, 2004, hal. 565

${ }^{6}$ UU RI No. 41 Tahun 2004, tentang Wakaf Bab I Pasal I. Pengertian diatas hampir sama dengan peraturan terdahulu (KHI) Buku III Hukum Perwakafan Bab I Pasal 215
} 
diambil tanpa mengkonsumsi harta benda itu sendiri. Oleh karenanya wakaf identik dengan tanah, kuburan, masjid, langgar, meskipun adapula wakaf buku-buku, mesin pertanian, binatang ternak, saham dan aset, serta uang tunai (wakaf tunai/cash waqf). Dengan demikian, secara garis besar wakaf dapat dibagi dalam dua kategori pertama direct wakaf dimana aset yang ditahan/diwakafkan dapat menghasilkan manfaat/jasa yang kemudian dapat digunakan oleh orang banyak (beneficiaries) seperti rumah ibadah, sekolah dan lain-lain. Kedua adalah wakaf investasi (aset yang diwakafkan digunakan untuk investasi). Wakaf aset ini dikembangkan untuk menghasilkan produk atau jasa yang dapat dijual untuk menghasilkan pendapatan, dimana pendapatan tersebut kemudian digunakan untuk membangun fasilitasfasilitas umum seperti masjid, pusat kegiatan umat Islam dan lain-lain.

\section{B. Sejarah Perwakafan di Indonesia}

\section{Wakaf pada Zaman Hindia Belanda}

Pelaksanaan hukum wakaf di Indonesia semula masih sangat sederhana, tidak disertai administrasi, cukup dilakukan ikrar (pernyataan) secara lisan saja tanpa mempertimbangkan legalitas hukum positif ke Indonesiaan diperparah lagi dengan tidak diadministrasikannya dengan baik setiap terjadinya ikrar wakaf dan harta-harta wakaf. Pada perjalanannya kemudian (sampai sekarang) terdapat tanah-tanah wakaf yang memunculkan permasalahan seperti: bentuknya yang hilang atau di ambil alih oleh orang-orang yang tidak bertanggung jawab, sengketa melalui pengadilan dan lain-lain. Bahkan pada periode tahun 1500 - 1600, di kantor wilayah Depag Provinsi Jawa Timur atau selama abad XVI tercatat hanya 6 (enam) buah wakaf yaitu tanah seluas $20.615 \mathrm{~m} 2 .^{7}$ Kemudian pada pertengahan kedua abad XVII terdapat 61 wakaf dengan luas $94.071 \mathrm{~m} 2$ (rata-rata $1.542 \mathrm{~m} 2$ perwakafan), yang terdiri dari 57 wakaf tanah kering dan 4 (empat) buah wakaf sawah, ${ }^{8}$ dan seiring dengan perkembangan dan pemahaman agama yang makin hari makin paripurna, maka pada pertengahan pertama pada abad XIX tercatat 79 buah wakaf yang terdiri dari 78 tanah kering dan sebuah wakaf sawah. Selanjutnya pada pertengahan kedua abad tersebut tercatat 224 buah wakaf terdiri dari 219 buah wakaf tanah kering dan 5 (lima) buah wakaf sawah. ${ }^{9}$

Data diatas menunjukan bahwa, walaupun ada trend kenaikan kesadaran berwakaf bagi umat Islam, akan tetapi pengadministrasiannya tidak terkontrol dengan baik atau bahkan dilakukan sekedarnya saja. Kita lihat saja, dari abad XVII terdapat 61 wakaf sampai pertengahan abad XIX hanya tercatat 224 buah wakaf. Ini juga berarti bahwa dalam kurun waktu 1 (satu ) abad lebih wakaf yang tercatat hanya mengalami kenaikan 163 tanah wakaf.

Perkembangan menggembirakan terlihat pada tahun 1905, pada masa pemerintahan Hindia Belanda. Tanah wakaf mulai diatur dengan Sirculair Van De Gonvernement Secretaris (surat edaran yang dikeluarkan oleh sekretaris gobernemen) 31 januari 1905 No. 435 (Bijblad 1905 No. 6196 tentang Toezicht Opden Bouw Van Mohammadeaanche Bedehuizen), yang isinya memerintahkan kepada para Bupati agar membuat daftar rumah ibadat Islam yang dibangun diatas tanah wakaf, agar tidak bertentangan dengan kepentingan umum seperti untuk pembuatan jalan dan pembuatan pasar. ${ }^{10}$

\footnotetext{
${ }^{7}$ Abdul Gofar, dalam Tim Dirjen Bimas Islam dan Penyelenggaraan Haji Depag RI, Kumpulan Hasil Seminar Perwakafan, Jakarta; Dirjen Bimas Islam dan Penyelenggaraan Haji Direktorat Pengembangan Zakat dan Wakaf, 2004, hal.43

${ }^{8}$ Ibid, hal. 54

${ }^{9}$ Ibid

${ }^{10}$ Imam Suhadi, Wakaf Untuk Kesejahteraan Umat, Yogyakarta; PT. Dama Bhakti Prima Yasa, 2002, hal. 4
} 
Dalam selang waktu 26 tahun, atau tepatnya pada tahun 1931 dikeluarkan surat edaran sekretaris Gobernemen tertanggal 4 Juni 1931 No.1961 (Bijblad 1931 No. 12573) tentang perlunya meminta izin secara resmi kepada Bupati terhadap orang-orang yang ingin berwakaf dan kemudian Bupati menilai permintaan izin tersebut dari sudut maksud perwakafannya dan tempat harta yang di wakafkan itu. ${ }^{11}$

Bijblad 1931 No. 12573 inipun kemudian menumbuhkan polemik baru ditengah-tengah masyarakat bahkan umat Islam bereaksi sangat keras terhadap surat edaran ini. Buntutnya pada tahun 1934, lahirlah Bijblad 1934 No. 13390. Bijblad ini sifatnya hanya mempertegas bijblad-bijblad sebelumnya, ditambah dengan pengaturan tentang penyelesaian persengketaan tentang penyelenggaraan shalat jum'at. Tentang yang terakhir ini, bijblad tidak menentukan secara tegas melainkan hanya menyerahkan kekurangan ini kepada Bupati, dengan catatan apabila para pihak yang bersangkutan memintanya. ${ }^{12}$ Sebagai apresiasi, "terlepas dari berbagai maksud dan tujuan", pemerintah Hindia Belanda pada tahun 1935 mengeluarkan edaran baru tentang perwakafan yaitu Bijblad 1935 No. 13480. Lahirnya bijblad 1935 No. 13480 ini pun sebenarnya hanya mempertegas ketentuan-ketentuan tentang wakaf yang telah diatur pada bijblad 1934 No. 13390 ditambah keterangan tentang maksud pendaftaran, yaitu agar Bupati mendapatkan kesempatan melihat dan meneliti dalam daftar yang tersedia apakah ada pelanggaran terhadap peraturan umum atau peraturan setempat dalam pelaksanaan wakaf 13

Dari beberapa surat edaran yang pernah dikeluarkan oleh sekretaris Gobernemen tersebut diatas, terlihat bahwa wakaf yang telah ada hanya untuk keperluan administratif semata atau dengan kata lain bahwa latar belakang lahirnya bijblad hanyalah untuk mengadministrasikan tanah-tanah wakaf agar tidak bertentangan dengan kepentingan pemerintah masa itu. Apalagi bijblad lahirnya hanya dari rumusan orang-orang yang tidak memiliki ikatan emosional dengan umat Islam (lahir dari orang-orang non muslim). Padahal disunnahkannya wakaf bukan untuk kepentingan administrasi semata, melainkan bagaimana instrumen wakaf dapat mengangkat harkat dan martabat umat Islam.

\section{Wakaf Pra Kemerdekaan, masa kemerdekaan dan Era Reformasi}

Masa pra kemerdekaan, lembaga perwakafan sering dilakukan oleh masyarakat yang beragama Islam. Hal ini merupakan konsekwensi logis dari banyaknya kerajaan-kerajaan Islam di Indonesia, seperti kerajaan Demak, kerajaan Pasai dan lain-lain.

Bahkan praktek pelembagaan wakaf yang selama ini dilakukan diberbagai negara telah di praktekkan di Indonesia. Walaupun tidak persis sama baik dengan sistem sekarang atau dalam ajaran Islam, akan tetapi esensi atau spirit ajaran wakaf memiliki kemiripan. Bahkan pelembagaan wakaf tersebut masih berlangsung sampai sekarang ini. Di Jawa Timur umpamanya, terdapat tanah "perdikan" adalah sebidang tanah yang merupakan pemberian raja kepada seseorang atau kelompok yang berjasa. Di lombok terdapat "tanah pareman" ialah tanah negara yang dibebaskan dari pajak "Landrente" yang hasilnya diserahkan kepada Desadesa, Subak dan kepada Candi untuk kepentingan bersama. Di Banten ada "Huma Serang" adalah ladang yang setiap tahun dikelola secara bersama-sama dan hasilnya dipergunakan untuk kepentingan bersama. Corak wakaf diatas hampir sama dengan wakaf ahli yaitu wakaf untuk ahli kerabat, untuk membantu kepentingan kehidupan mereka dan juga berbentuk tali

\footnotetext{
${ }^{11}$ Ibid

${ }^{12}$ Tim Dirjen Bimas Islam dan Penyelenggaraan Haji Depag RI, Kumpulan... , hal. 15

${ }^{13}$ Ibid, hal. 16
} 
asih dan silaturahim para ahli kerabat. Seperti yang terjadi pada masa Rasulullah, dalam Hadist Abu Thalhah tentang wakaf kebun Bai-Raha di samping masjid Madinah. ${ }^{14}$

Pada masa kemerdekaan, masalah wakaf mulai mendapat perhatian lebih dari Pemerintah Nasional, antara lain melalui Departemen Agama. Walaupun sebenarnya undang-undang tentang perwakafan tanah, lahir 15 tahun setelah Indonesia merdeka, namun sebelum lahirnya Undang-undang tentang perwakafan tanah, Pemerintah melalui Departemen Agama melahirkan beberapa petunjuk tentang pelaksanaan wakaf, antara lain :

a. Petunjuk tentang perwakafan tanah tanggal 22 Desember 1953.

b. Petunjuk tentang wakaf yang bukan milik kemasjidan, merupakan tugas bagian D (ibadah sosial) Jawatan Urusan Agama berdasarkan surat edaran Jawatan Urusan Agama tanggal 8 Oktober 1956 No.3/D/1956.

c. Petunjuk tentang prosedur perwakafan tanah berdasarkan Surat Edaran Jawatan Urusan Agama No.5/1956. ${ }^{15}$

Petunjuk dan surat edaran tentang wakaf baik produk pemerintah Kolonial Belanda maupun yang dibuat oleh Pemerintah Indonesia sendiri, ternyata masih banyak terdapat kelemahan disana sini, terutama belum memberikan kepastian hukum bagi tanah-tanah wakaf. Untuk menertibkan itu semua, perlu pembaharuan hukum agraria, maka kemudian pada tahun 1960 lahirlah Undang-undang No. 5 tahun 1960 tentang Peraturan Dasar Pokok Agraria, Lembaran Negara No. 104 tahun 1960 yang belakangan di kenal dengan nama Undang-undang Pokok Agraria (UUPA). ${ }^{16}$

Dalam UUPA, masalah wakaf dapat kita temui pada Pasal 5, Pasal 14, dan Pasal 49 yang membuat rumusan sebagai berikut :

a. Pasal 5 mengatakan bahwa Hukum Agraria yang berlaku atas bumi, air dan ruang angkasa ialah hukum adat, sepanjang tidak bertentangan dengan kepentingan nasional dan negara.........segala sesuatu dengan mengindahkan unsur-unsur yang bersandar pada hukum agama. Dilihat dalam rumusan pasal ini, jelaslah bahwa hukum adatlah yang menjadi dasar hukum agraria Indonesia, yaitu hukum Indonesia asli yang tidak tertulis dalam bentuk perundang-undangan Republik Indonesia yang disana sini mengandung unsur agama yang telah diresipien dalam lembaga hukum adat, khususnya lembaga wakaf.

b. Pasal 14 ayat (1) mengatakan bahwa pemerintah dalam rangka sosialisme Indonesia membuat suatu rencana umum mengenai persediaan, peruntukkan dan penggunaan bumi, air dan ruang angkasa serta kekayaan alam yang terkandung di dalamnya untuk keperluan negara, untuk keperluan peribadatan dan keperluan suci lainnya sesuai dengan dasar Ketuhanan Yang Maha Esa dan seterusnya. Pada rumusan pasal 14 ayat (1) ini, terkandung makna adanya amar kepada pemerintah Pusat dan Pemerintah Daerah untuk membuat skala prioritas, penyediaan, peruntukkan dan penggunaan bumi, air dan ruang angkasa dalam bentuk peraturan yang dibuat oleh pemerintah pusat maupun pemerintah daerah, termasuk pengaturan tentang penggunaan tanah untuk keperluan peribadatan dan kepentingan suci lainnya.

c. Pasal 49 mengatakan bahwa:

1) Hak milik tanah-tanah badan keagamaan dan sosial. Sepanjang dipergunakan untuk usaha dalam bidang keagamaan sosial, diakui dan dilindungi. Badan-badan tersebut

\footnotetext{
${ }^{14}$ Mujtaba Ismail, Fiqh Wakaf menurut UU No.41 tahun 2004, Makalah Sosialisasi UU 41 tahun 2004 dan Lokakarya Depag Kaltim Tahun 2006 tgl. 21 Maret 2006, hal. 3

${ }^{15}$ Abdul Gofar', Op.Cit, hal. 46

${ }^{16}$ Lihat: Undang-undang No. 5 tahun 1960 tentang Peraturan Dasar Pokok Agraria, Lembaran Negara No. 104 tahun 1960
} 
dijamin pula akan memperoleh tanah yang cukup untuk bangunan dan usahanya dalam bidang keagamaan dan sosial.

2) Untuk keperluan peribadatan dan keperluan suci lainnya sebagai dimaksud pada pasal 14 dapat diberikan tanah yang dikuasai langsung oleh negara dengan hak pakai.

3) Perwakafan tanah milik dilindungi dan diatur dengan peraturan pemerintah.

Pasal ini memberikan ketegasan bahwa soal-soal yang bersangkutan dengan peribadatan dan keperluan suci lainnya dalam hukum agraria akan mendapatkan perhatian sebagaimana mestinya. Dan sebagai realisasi ketentuan pasal 49 ayat (3) diatas, kemudian dikeluarkanlah Peraturan Pemerintah No. 28 tahun 1977 tanggal 17 Mei 1977.

Peraturan Pemerintah nomor 28 tahun 1977 yang selanjutnya disebut PP No. 28 tahun 1977 terdiri atas tujuh bab, delapan belas pasal, meliputi pengertian tentang wakaf, syaratsyarat sahnya wakaf, fungsi wakaf, tata cara mewakafkan dan pendaftaran wakaf, perubahan, penyelesaian perselisihan dan pengawasan wakaf, ketentuan pidana dan ketentuan peralihan.

Dikeluarkannya Peraturan Pemerintah No. 28 tahun 1977 tentang perwakafan tanah milik, yang disertai aturan pelaksanaannya, sebenarnya bertujuan untuk menjadikan tanah wakaf suatu lembaga keagamaan yang dapat dipergunakan sebagai salah satu sarana guna pengembangan kehidupan keagamaan, khususnya bagi umat yang beragama Islam, untuk mencapai masyarakat yang adil dan makmur berdasarkan Pancasila. ${ }^{17}$ Tujuan ini sebenarnya berdasarkan kenyataan bahwa keadaan perwakafan tanah tidak atau belum diketahui jumlahnya, bentuknya, penggunaan dan pengelolaannya disebabkan tidak adanya ketentuan administrasi yang mengatur tentang itu. Dengan dikeluarkannya PP No. 28 tahun 1977 merupakan hal urgen, terutama untuk kepentingan seperti tersebut diatas, dan untuk memberi ketetapan hukum dan kejelasan hukum tentang tanah perwakafan sesuai pasal 49 ayat (3) UUPA. ${ }^{18}$ Dengan demikian, hadirnya PP No. 28 tahun 1977 berbagai penyimpangan dan sengketa wakaf diharapkan dapat diminimalisir. Untuk itu, upaya yang telah dilakukan oleh Departemen Agama untuk mengurangi penyimpangan dan sengketa wakaf pasca lahirnya PP 28 tahun 1977, adalah dengan melakukan langkah-langkah, yaitu :

a. Mendata seluruh tanah wakaf hak milik di seluruh wilayah tanah air. Pada pendataan tanah wakaf hak milik ini sebagai langkah untuk memastikan jumlah wakaf tanah di Indonesia untuk kemudian di jadikan tolok ukur pengelolaan, pemberdayaan dan pembinaan tanah wakaf.

b. Memberikan sertifikat tanah wakaf yang belum di sertifikasi dan memberikan bantuan advokasi terhadap tanah wakaf yang bermasalah. ${ }^{19}$

Bahkan kita juga patut salut kepada pemerintah lebih khusus Departemen Agama dalam usahanya membackup Pasal 49 ayat (3) UUPA dan PP No. 28 tahun 1977 dengan menerbitkan beberapa Peraturan Menteri, Intruksi Menteri dan lain-lain, yang berhubungan satu dengan yang lainnya dalam masalah wakaf. Peraturan tersebut antara lain :

a. Peraturan Menteri dalam negeri No. 6 tahun 1977 tentang tata pendaftaran tanah mengenai Perwakafan Tanah Milik.

b. Peraturan Menteri Agama No. 1 tahun 1978 tentang peraturan pelaksanaan peraturan pemerintah No. 28 tahun 1977 tentang Perwakafan Tanah Milik.

\footnotetext{
${ }^{17}$ Imam Suhadi, Op.Cit, hal. 5

${ }^{18}$ Tim Peningkatan Zakat dan Wakaf Depag RI, Perkembangan Pengelolaan Wakaf di Indonesia, Jakarta; Direktorat Pengembangan Zakat dan Wakaf Direktorat Jeneral Bimbingan Masyarakat Islam dan Penyelenggaraan Haji, 2005, hal. 16

${ }^{19}$ Ibid, hal. 17 - 18
} 
c. Keputusan Menteri Agama No. 73 tahun 1978 tentang pendelegasian wewenang kepada Kepala Kantor Wilayah Departemen Agama Propinsi/setingkat di seluruh Indonesia untuk mengangkat/memberhentikan setiap kepala KUA kecamatan sebagai PPAIW.

d. Keputusan Menteri Agama No. 326 tahun 1989 tentang pembentukan tim koordinasi penertiban tanah wakaf seluruh Indonesia Tingkat Pusat.

e. Keputusan Menteri Agama No. 126 tahun 1990 tentang Penyempurnaan Lampiran Keputusan Menteri Agama No. 326 tahun 1989 tentang susunan personalia tim koordinasi penertiban tanah wakaf seluruh Indonesia Tingkat Pusat.

f. Keputusan Menteri Agama No. 196 tahun 1991 tentang Penyempurnaan Lampiran Keputusan Menteri Agama No. 126 tahun 1990 tentang susunan personalia tim koordinasi penertiban tanah wakaf seluruh Indonesi tingkat pusat.

g. Intruksi bersama Menteri Agama dan Menteri Dalam Negeri No. 1 tahun 1978 tentang pelaksanaan Peraturan Pemerintah No. 28 tentang Perwakafan Tanah Milik tahun 1977.

h. Intruksi bersama Menteri Agama No. 3 tahun 1978 tentang petunjuk pelaksanaan Keputusan Menteri Agama No. 73 tahun 1978 tentang pendelegasian wewenang kepada kepala Kantor Urusan Agama Kecamatan sebagai Pejabat Pembuat Akta Ikrar Wakaf (PPAIW).

i. Surat Dirjen Bimas Islam dan Urusan Haji No. DII/5/Ed/07/1981 tentang pendaftaran perwakafan tanah milik.

j. Surat Dirjen Bimas Islam dan Urusan Haji No. DII/1/KU.03.2/363/1986 tentang Bea Menterai, Akta Nikah, Akta Ikrar Wakaf dan sebagainya.

k. Surat Edaran Dirjen Bimas Islam dan Urusan Haji No. DII/5/HK/007/901/1989 tentang petunjuk perubahan status/tukar menukar tanah wakaf.

Bahkan selain peraturan menteri, instruksi menteri dan lain-lain seperti tersebut diatas, pada tanggal 10 Juni 1991 di keluarkan Instruksi Presiden RI No.1 tahun 1991 tentang Kompilasi Hukum Islam (KHI) di Indonesia. Sebagai pedoman bagi para hakim-hakim peradilan agama dan bagi para pencari keadilan dalam perkawinan dan kewarisan di samping mengatur tentang hukum perwakafan.

Hadirnya KHI sebenarnya telah melalui proses panjang, termasuk di dalamnya lokakarya Alim Ulama Indonesia yang diadakan di Jakarta pada tanggal 2 sampai dengan 5 Februari 1988 yang pada intinya menerima dengan baik tiga rancangan buku KHI, yaitu Buku I tentang Hukum Perkawinan, Buku II tentang Hukum Kewarisan, dan Buku III tentang Hukum perwakafan. ${ }^{20}$ Dilihat dari tujuan pembentukannya, KHI di arahkan kepada Unifikasi mazhab dalam hukum Islam di Indonesia, bahkan KHI merupakan satu bentuk terdekat dengan kodifikasi hukum dalam pembangun hukum Nasional Indonesia. ${ }^{21}$

Namun, kalau kita telaah lebih dalam lagi, ketentuan wakaf yang terdapat pada KHI hampir sama dengan ketentuan wakaf yang terdapat dalam PP No.28 tahun 1977. Berikut ketentuan tentang wakaf yang dimaksud :

\footnotetext{
${ }^{20}$ Lihat Inpres, No.1 tahun 1991 tentang Kompilasi Hukum Islam

${ }^{21}$ Tahir Azhari, Wakaf dan Sumber Daya Ekonomi, Suatu Pendekatan Teoritis, Mimbar Hukum, No.7 Tahun II, Jakarta; Al-Hikmah, 1992, hal. 17
} 


\section{Persamaan antara PP. No. 28 tahun 1977 dengan Kompilasi Hukum Islam (KHI)}

\begin{tabular}{|c|c|}
\hline PP No.28 tahun 1977 & K H I \\
\hline $\begin{array}{c}\text { Pengertian wakaf, wakif, ikrar,dan } \\
\text { Nazhir (Pasal 1) }\end{array}$ & $\begin{array}{c}\text { Pengertian wakaf,wakif, ikrar, benda } \\
\text { wakaf Nazhir dan pejabat pembuat akta } \\
\text { ikrar wakaf (Pasal 215) }\end{array}$ \\
\hline Fungsi wakaf (pasal 2) & Fungsi wakaf (pasal 216) \\
\hline $\begin{array}{c}\text { Unsur-unsur dan syarat-syarat wakaf } \\
\text { (pasal 3-6) }\end{array}$ & $\begin{array}{c}\text { Unsur-unsur dan syarat-syarat wakaf } \\
\text { (pasal 217-219) }\end{array}$ \\
\hline Kewajiban dan hak nazhir (pasal 7-8) & Perihal nazhir (pasal 220-222) \\
\hline Tata cara wakaf (pasal 9) & Tata cara wakaf (pasal 223) \\
\hline $\begin{array}{c}\text { Tata cara pendaftaran wakaf tanah } \\
\text { (pasal 10) }\end{array}$ & Pendaftaran benda wakaf (pasal 224) \\
\hline $\begin{array}{c}\text { Perubahan peruntukkan, penyelesaian } \\
\text { perselisihan dan pengawasan tanah } \\
\text { wakaf (pasal 11 - 13) }\end{array}$ & Perubahan benda wakaf (pasal 225) \\
\hline $\begin{array}{c}\text { Ketentuan pidana (pasal 14-15) } \\
\text { Ketentuan peralihan (pasal 16-17) }\end{array}$ & Penyelesaian perselisihan benda wakaf \\
( pasal 226 )
\end{tabular}

Meskipun kehadiran KHI merupakan elaborasi terhadap PP No. 28 tahun 1977. Namun antara keduanya terdapat beberapa perbedaan antara lain:

Dalam PP No. 28 tahun 1977, obyek wakaf yang diatur hanyalah tanah milik berdasarkan pada UUPA, sehingga obyek wakaf menurut PP No. 28 tahun 1977 sangat terbatas sedangkan dalam KHI, obyek wakaf tidak hanya berupa tanah milik sebagai mana disebutkan dalam PP No. 28 tahun 1977 akan tetapi lebih luas dari itu sebagaimana disebutkan dalam pasal 215, point (1); wakaf adalah perbuatan hukum seseorang atau kelompok orang atau badan hukum yang memisahkan sebagian dari benda miliknya dan melembagakannya untuk selama-lamanya guna kepentingan ibadat atau keperluan hukum lainnya sesuai dengan ajaran Islam, dan point (4) benda wakaf adalah segala benda, baik benda bergerak atau tidak bergerak yang memiliki daya tahan yang tidak hanya sekali pakai dan bernilai menurut ajaran agama Islam.

Di samping itu KHI juga mengatur tentang ketentuan-ketentuan yang belum diatur dalam PP No. 28 tahun 1977, misalnya pembatasan jumlah Nazhir, sekurang-kurangnya terdiri dari 3 orang dan sebanyak-banyaknya 10 orang yang diangkat oleh Kepala Kantor Urusan Agama Kecamatan atas saran Majelis Ulama Kecamatan dan Camat setempat. ${ }^{22}$ Pengawasan terhadap pelaksanaan tugas dan tanggung jawab Nazhir. ${ }^{23}$ Kedudukan dan peranan yang lebih luas kepada Majelis Ulama Indonesia Kecamatan dan Camat. ${ }^{24}$

\footnotetext{
${ }^{22} \mathrm{KHI}$ pasal 219 ayat (5)

${ }^{23}$ KHI Pasal 227

${ }^{24}$ KHI Pasal 219 ayat (3), dan ayat (5), pasal 220 ayat (2), pasal 221 ayat (2), pasal 222, pasal 225 ayat (2), pasal 227
} 
Walaupun dalam Inpres No. 1 tahun 1991 telah diadakan pengembangan mengenai obyek wakaf yang tidak hanya berupa tanah milik sebagaimana disebutkan dalam PP No. 28 tahun 1977, akan tetapi Inpres No. 1 tahun 1991 masih dirasakan terdapat kekurangan di sana sini, misalkan belum merinci benda apa saja yang dapat diwakafkan dan berapa banyak benda miliknya yang boleh diwakafkan, begitu pula dengan hak dan kewajiban Nazhir. ${ }^{25}$

Terlepas dari adanya kelebihan dan kekurangan PP No. 28 tahun 1977 tentang perwakafan tanah milik beserta peraturan pelaksanaannya dan KHI melalui Inpres No. 1 tahun1991 Jo Keputusan Menteri Agama RI No. 154 tahun 1991, yang sudah pernah dijadikan rujukan pengelolaan wakaf. Merupakan usaha awal pembaharuan hukum nasional di bidang perwakafan, dan berawal dari peraturan-peraturan tersebut diataslah lahirnya UU No. 41 tahun 2004 tentang wakaf.

Undang-undang No. 41 tahun 2004 tentang wakaf, lahir pada awalnya berdasarkan atas bergulirnya wacana wakaf tunai yang di gagas oleh Prof. M. A. Mannan (Ekonom berkebangsaan Bangladesh), dimana wakaf tunai sebagai instrumen finansial (Financial Instrument), keuangan sosial dan perbankan sosial (social finance and voluntary sector banking). ${ }^{26}$ Wacana tentang wakaf tunai ini kemudian membuahkan inisiatif dari Direktorat Pengembangan Zakat dan wakaf Depag RI untuk kemudian mengirim surat bernomor: Dt. III/5/BA.03.2/2772/2002 tertanggal 26 April 2002 kepada Majelis Ulama Indonesia (MUI) mengenai permohonan fatwa tentang wakaf uang. Dan pada tanggal 28 Shafar $1423 \mathrm{H} / 11$ Mei 2002 M keluarlah fatwa MUI tentang wakaf uang yang ditandatangani oleh ketua komisi fatwa KH. Ma'ruf Amin dan sekretaris komisi Drs. Hasanudin, M.Ag, dengan isi fatwa antara lain: wakaf uang hukumnya jawaz (boleh). ${ }^{27}$

Pasca lahirnya fatwa MUI tentang wakaf uang, pengembangan wakaf semakin mendapat legitimasi, paling tidak pada tataran landasan hukum keagamaan, bahkan dalam tataran lingkaran birokrasi kepemerintahan, Direktorat pengembangan zakat dan wakaf Depag RI kemudian mengusulkan pembentukan Badan Wakaf Indonesia (BWI).

Ide pembentukan BWI diusulkan oleh Menteri Agama RI secara langsung kepada Presiden RI, Megawati Soekarno Putri melalui surat No. MA/320/2002 tertanggal 5 September 2002. ${ }^{28}$ Usul pembentukan BWI Menteri Agama RI kepada Presiden berbuah usulan dari Sekretariat Negara agar Depag RI memprakarsai untuk menyusun draft Rancangan UndangUndang (RUU) tentang wakaf dan tepat pada tanggal 27 Oktober 2004, atau seminggu setelah Presiden pertama (Dr.H.Susilo Bambang Yudhoyono) yang dipilih rakyat secara langsung di lantik oleh MPR, RUU tentang wakaf di Undangkan menjadi UU RI No. 41 tahun 2004 tentang wakaf dan dicatat dalam Lembaran Negara RI Tahun 2004 No. $159 .{ }^{29}$

Jika dibandingkan dengan beberapa peraturan perundang-undangan tentang wakaf yang sudah ada selama ini, dalam undang-undang No. 41 tahun 2004 tentang wakaf terdapat

\footnotetext{
${ }^{25}$ Tulus, dalam Tim Peningkatan Zakat dan Wakaf Depag RI, Perkembangan Pengelolaan Wakaf di Indonesia, Jakarta; Direktorat Pengembangan Zakat dan Wakaf Direktorat Jenderal Bimbingan Masyarakat Islam dan Penyelenggaraan Haji, 2005, hal. 217

${ }^{26}$ Tim Dirjen Bimas Islam dan Penyelenggaraan Haji Depag RI, Proses lahirnya UU No. 41 tahun 2004 tetang wakaf, Jakarta; Direktorat Pengembangan Zakat dan Wakaf Ditjen Bimas Islam dan Penyelenggaraan Haji, 2005, hal.1

${ }^{27}$ Lihat Keputusan Fatwa Komisi Fatwa MUI tentang Wakaf Uang Tanggal 28 Shafar 1423 H / 11 Mei 2002 M

${ }^{28}$ Kajian lebih lanjut lihat Tim Dirjen Bimas Islam dan Penyelenggara Haji Depag RI, Proses... , hal. 15 - 20

${ }^{29}$ Perlu juga dicatat bahwa proses pengundangan Undang-Undang tentang wakaf ini, berada dalam masa transisi kepemimpinan, yaitu pergantian Presiden $\mathrm{Hj}$. Megawati Soekarno Putri kepada Dr. H. Susilo Bambang Yudhoyono atau proses administrasi dan pembahasan RUU pada masa pemerintahan Kabinet Gotong Royong sedangkan pengesahan pada masa Kabinet Indonesia Bersatu.
} 
beberapa hal baru sebagai pengembangan peraturan perundang-undangan pendahulunya. Beberapa diantaranya adalah mengenai masalah nazhir, ${ }^{30}$ harta benda yang diwakafkan (mauquf bih), ${ }^{31}$ dan peruntukan harta wakaf (mauquf 'alaih), serta adanya tuntutan untuk sesegera mungkin membentuk Badan Wakaf Indonesia (BWI). ${ }^{32}$ Berkenaan dengan masalah nazhir, karena dalam undang-undang ini (Pasal 16) yang dikelola bukan hanya benda tidak bergerak lazimnya wakaf sekarang ini, tetapi juga mengelola benda wakaf yang bergerak seperti: uang, logam mulia, surat berharga, kendaraan, hak atas kekayaan intlektual, hak sewa dan lain-lain, maka keidealan seorang nazhirpun dituntut untuk dapat mengelola benda-benda tersebut.

Hadirnya undang-undang RI No. 41 tahun 2004 tentang wakaf, merupakan undangundang yang dinanti-nantikan oleh segenap Bangsa Indonesia terutama yang memeluk agama Islam. Hal ini tergambar pada pandangan dan usulan dalam Rapat Dengar Pendapat Umum (RDPU) atas undangan Komisi VI DPR yang dihadiri ormas-ormas Islam dan merupakan representasi Masyarakat Muslim Indonesia, serta BAZNAS/LAZNAS. ${ }^{33}$ Bahkan bagi Uswatun Hasanah adanya undang-undang tentang wakaf di Indonesia merupakan suatu keharusan. Hal ini didasarkan atas keprihatinan beliau terhadap pengelolaan dan pengembangan wakaf di Indonesia yang memiliki jumlah tanah wakaf yang cukup banyak (tanpa merinci jumlah), tetapi sampai saat ini keberadaan wakaf belum berdampak positif bagi kesejahteraan sosial dan ekonomi umat di bandingkan dengan negara lain seperti : Mesir, Saudi Arabia, Yordania dan lain-lain. ${ }^{34}$

Paling tidak, UU Wakaf ini merupakan penyempurnaan dari beberapa peraturan perundang-undangan wakaf yang sudah ada dengan menambah hal-hal baru sebagai upaya pemberdayaan wakaf secara produktif dan profesional atau bahkan substansi dari Undangundang Wakaf berupaya untuk :

1. Mengunifikasikan berbagai peraturan tentang wakaf;

2. Menjamin kepastian hukum dalam bidang wakaf;

3. Melindungi dan memberikan rasa aman bagi wakif, nazhir baik kelompok orang, organisasi maupun badan hukum;

4. Sebagai instrumen untuk mengembangkan rasa tanggung jawab bagi para pihak yang mendapat kepercayaan mengelola wakaf;

5. Sebagai koridor kebijakan publik dalam rangka advokasi dan penyelesaian perkara dan sengketa wakaf.

6. Mendorong optimalisasi pengelolaan dan pengembangan wakaf. ${ }^{35}$

Dengan adanya Undang-undang wakaf tersebut yang memiliki semangat pemberdayaan benda-benda wakaf secara produktif, diharapkan dapat tercipta kehidupan masyarakat yang lebih adil dan sejahtera. Namun, regulasi peraturan perundang-undangan dibidang lain seperti keuangan dan perekonomian khususnya perekonomian berbasis syari'ah harus segera

\footnotetext{
${ }^{30}$ Lihat UU RI No. 41 tahun 2004 tentang wakaf bagian kelima pasal 9, 10, 11, 12, 13, dan 14

${ }^{31}$ Ibid, bagian keenam pasal 15 dan 16

${ }^{32}$ Ibid, Bab VI Bagian Pertama Pasal 47, 48, 49, dan 50

${ }^{33}$ Undangan RDPU, yaitu : MUI, NU, Persis, Muhammadiyah, BAZNAS, LAZ Dompet Dhuafa Republika, LAZ Pos Keadilan Peduli Umat (PKPU) dan LAZ Al- Falah Informasi lebih lanjut, lihat : Tim Dirjen Bimas Islam dan Penyelenggaraan Haji Depag RI, Proses... , hal. 85 - 97

${ }^{34}$ Uswatun Hasanah, Implementasi UU No. 41 tahun 2004 tentang wakaf sebagai regulasi wakaf di
} Indonesia, makalah di sampaikan pada seminar manajemen wakaf berdasarkan UU No. 41 tahun 2004, IMZ, tanggal 20 April 2005 di Hotel Sofyan Tebet Jakarta, hal. 1

${ }^{35}$ Tulus, Implementasi UU No. 41 tahun 2004 tentang wakaf, Makalah di sampaikan pada seminar manajemen wakaf berdasarkan UU No. 41 tahun 2004, IMZ, tanggal 20 April 2005 di Hotel Sofyan Tebet Jakarta, hal. 3 
dilakukan untuk mendukung semangat Undang-undang wakaf dalam rangka pemberdayaan wakaf secara produktif.

\section{PEMBAHASAN}

Pada Zaman Hindia Belanda, pelaksanaan hukum wakaf masih sangat sederhana, tidak disertai administrasi dan cukup dilakukan ikrar secara lisan saja karena memang legalitas hukum yang mengatur tentang perwakafan belum memadai sehingga kemudian banyak harta wakaf yang hilang dan diambil alih oleh orang-orang yang tidak bertanggung jawab.

Perkembangan menggembirakan terlihat pada tahun 1905 yang ditandai dengan dikeluarkannya Sirculair Van De Gonvernement Secretaris (Surat edaran yang dikeluarkan oleh Sekretaris Gobernement) 31 Januari 1905 No. 435 (Bijblad 1905 No. 6196 tentang Toezicht Opden Bouw Van Mohammadea Anche Bedehuizen). Selanjutnya pada tahun 1931 atau persis 26 tahun kemudian dikeluarkan lagi edaran sekretaris Gobernemen tertanggal 4 Juni 1931 No. 1961 (Bijblad 1931 No. 12573) tentang perlunya meminta izin secara resmi kepada Bupati terhadap orang-orang yang ingin berwakaf untuk kemudian Bupati menilai permintaan izin tersebut dari sudut maksud perwakafannya dan tempat harta yang diwakafkan itu. Bijblad ini pun kemudian berbuah Bijblad 1934 No. 13390 yang mempertegas kembali Biblad-bijblad sebelumnya dengan tambahan pengaturan penyelesaian persengketaan tentang penyelenggaraan shalat jum'at. Bijblad 1934 No. 13390 ini pun kemudian menuai persoalan baru bagi masyarakat miskin Indonesia yang kemudian lahirlah Bijblad 1935 No. 13480.

Dari beberapa surat edaran yang pernah dikeluarkan oleh sekretaris Gobernemen tersebut diatas, terlihat bahwa wakaf yang telah ada hanya untuk keperluan administratif semata atau dengan kata lain bahwa latar belakang lahirnya bijblad hanyalah untuk mengadministrasikan tanah-tanah wakaf agar tidak bertentangan dengan kepentingan pemerintah masa itu. Apalagi bijblad lahirnya hanya dari rumusan orang-orang yang tidak memiliki ikatan emosional dengan umat Islam (lahir dari orang-orang non muslim). Padahal disunnahkannya wakaf bukan untuk kepentingan administrasi semata, melainkan bagaimana instrumen wakaf dapat mengangkat harkat dan martabat umat Islam.

Sementara masa pra kemerdekaan yang ditandai dengan masih hidupnya kerajaankerajaan Islam di Indonesia juga memberikan andil terhadap pelaksanaan wakaf di Indonesia yang sampai sekarang ini masih dirasakan seperti di Jawa Timur ada tanah Perdikan, di Lombok ada tanah Pareman dan di Banten ada Huma Serang.

Lima Belas tahun setelah Indonesia merdeka, masalah wakaf mulai perhatian serius dari otoritas pemerintahan, ini terbukti dengan lahirnya beberapa petunjuk tentang perwakafan tanah tanggal 22 Desember 1953, petunjuk tentang wakaf yang bukan milik kemasjidan merupakan tugas bagian D (Ibadah Sosial) Jawatan Urusan Agama (Surat Edaran Jawatan Urusan Agama tanggal 8 Oktober 1956 No. 3/D/1956 dan Edaran Jawatan Urusan Agama No. 5/1956). Tiga petunjuk tentang perwakafan itu kemudian melahirkan Undang-undang Pokok Agraria (UUPA) No. 5 tahun 1960 yang beberapa pasal (pasal 5, 14 dan 49) merupakan aturan perwakafan dan sebagai realisasi dari UUPA ini lahirlah Peraturan Pemerintah No. 28 tahun 1977 tanggal 17 Mei 1977.

Dari banyaknya aturan perwakafn, mulai masa pra kemerdekaan dan setelah Indonesia merdeka, sangat terasa bahwa regulasi perwakafan kering akan aturan pelaksanaannya. Setelah bertahun-tahun terjadinya stagnasi regulasi perwakafan, pada tahun 1977 lahirlah Peraturan Pemerintah no. 28 tahun tahun 1977. Inilah era baru perwakafan di Indonesia dimana Peraturan Pemerintah ini bertujuan untuk menjadikan tanah wakaf sebagai suatu lembaga keagamaan khususnya bagi umat Islam. Peraturan Pemerintah No. 28 tahun 1977 ini kemudian 
salah satu yang menjadi dasar lahirnya peraturan/perundang-undangan tentang wakaf seperti Kompilasi Hukum Islam bahkan yang monomental adalah Undang-undang No. 41 tahun 2004 tentang wakaf.

\section{PENUTUP}

\section{Kesimpulan}

Diskursus perwakafan sebenarnya merupakan proses yang sudah berjalan lama. Regulasi perwakafan yang di ekplorasi dari makalah ini dimulai dari masa Hindia Belanda, pra kemerdekaan, masa kemerdekaan dan era reformasi.

Dari deskripsi singkat, terlihat jelas bahwa Bijblad yang pernah beredar pada masa Hindia Belanda dan pra kemerdekaan merupakan usaha untuk mengadministrasikan harta wakaf semata. Sementara pada masa kemerdekaan dan era reformasi, perlakuan terhadap harta wakaf menuju kepada unifikasi wakaf menuju kesejahteraan umat.

\section{DAFTAR PUSTAKA}

\section{Literatur :}

Abu Bakr Jabir Al-Jazairi, Ensiklopedi Muslim (Minhajul Muslim), Alih Bahasa Fadli Bahri, Cet.VII, Jakarta; PT. Darul Falah, 2004

Achmad Azhar Basyir dalam Imam Suhadi, Wakaf Untuk Kesejahteraan Umat, Yogyakarta; PT. Dama Bhakti Prima Yasa, 2002

Imam Suhadi, Wakaf Untuk Kesejahteraan Umat, Yogyakarta; PT. Dama Bhakti Prima Yasa, 2002

Inpres, No.1 tahun 1991tentang Kompilasi Hukum Islam

John L. Esposito, Ensklopedi Oxford Dunia Islam Modern, Jilid 6, Alih Bahasa Eva Y.N dkk, Cet. I, Bandung; Mizan, 2001

Keputusan Fatwa Komisi Fatwa MUI tentang Wakaf Uang Tanggal 28 Shafar 1423 H / 11 Mei $2002 \mathrm{M}$

Mohammad Daud Ali, Sistem Ekonomi Islam; Zakat dan wakaf, Cet. I, Jakarta; UI Press, 1988

Mujtaba Ismail, Fiqh Wakaf menurut UU No.41 tahun 2004, Makalah Sosialisasi UU 41 tahun 2004 dan Lokakarya Depag Kaltim Tahun 2006 tgl. 21 Maret 2006

Tahir Azhari, Wakaf dan Sumber Daya Ekonomi, Suatu Pendekatan Teoritis, Mimbar Hukum, No.7 Tahun II, Jakarta; Al-Hikmah, 1992

Tim Ditjen Bimas Islam dan Penyelenggara Haji Depag RI, Klasifikasi Pemanfaatan Tanah Wakaf se Sumatera dan Kalimantan, Direktorat Pengembangan Zakat dan Wakaf Jakarta; Ditjen Bimas Islam dan Penyelenggara Haji, 2005

Tim Dirjen Bimas Islam dan Penyelenggaraan Haji Depag RI, Kumpulan Hasil Seminar Perwakafan, Jakarta; Dirjen Bimas Islam dan Penyelenggaraan Haji Direktorat Pengembangan Zakat dan Wakaf, 2004

Tim Peningkatan Zakat dan Wakaf Depag RI, Perkembangan Pengelolaan Wakaf di Indonesia, Jakarta; Direktorat Pengembangan Zakat dan Wakaf Direktorat Jeneral Bimbingan Masyarakat Islam dan Penyelenggaraan Haji, 2005 
Tim Peningkatan Zakat dan Wakaf Depag RI, Perkembangan Pengelolaan Wakaf di Indonesia, Jakarta; Direktorat Pengembangan Zakat dan Wakaf Direktorat Jenderal Bimbingan Masyarakat Islam dan Penyelenggaraan Haji, 2005

Tim Dirjen Bimas Islam dan Penyelenggaraan Haji Depag RI, Proses lahirnya UU No. 41 tahun 2004 tetang wakaf, Jakarta; Direktorat Pengembangan Zakat dan Wakaf Ditjen Bimas Islam dan Penyelenggaraan Haji, 2005

Tulus, Implementasi UU No. 41 tahun 2004 tentang wakaf, Makalah di sampaikan pada seminar manajemen wakaf berdasarkan UU No. 41 tahun 2004, IMZ, tanggal 20 April 2005 di Hotel Sofyan Tebet Jakarta, hal 41

Uswatun Hasanah, Implementasi UU No. 41 tahun 2004 tentang wakaf sebagai regulasi wakaf di Indonesia, makalah di sampaikan pada seminar manajemen wakaf berdasarkan UU No. 41 tahun 2004, IMZ, tanggal 20 April 2005 di Hotel Sofyan Tebet Jakarta

\section{Perundang-Undangan :}

Undang-undang No. 5 tahun 1960 tentang Peraturan Dasar Pokok Agraria, Lembaran Negara No. 104 tahun 1960

UU RI No. 41 Tahun 2004 tentang Wakaf 